\title{
研究速報
}

\section{重み付き非等方ボロノイ分割による線埋め込みステンドグラ ス画像}

\author{
Line-Embedding Stained Glass Images by Weighted Anisotropic Voronoi \\ Tessellation
}

学生会員 王 濤 ${ }^{\dagger}, \quad$ 浦 浜 喜 一†

Tao Wang ${ }^{\dagger}$ and Kiichi Urahama ${ }^{\dagger}$

\begin{abstract}
We present a non-photorealistic rendering method for generating stained glass images in which a line drawing is embedded. An input image is decomposed into cells by using a weighted anisotropic Voronoi tessellation on the basis of the distance transform of the input line drawing. Anisotropy and weighting are useful for preserving input lines embedded in stained glass images.
\end{abstract}

キーワード：ノンフォトリアリスティックレンダリング, ポアソンディスクサンプリング, ステンドグラス画像, ボロノイ分割

1. ま え がき

ステンドグラスはカラー写真を基にして作られる ことが多いが，図 1 のようにラフスケッチの線画か ら作られることもある。図 1(a),(b) はウェブページ http://www.beastwithin.org/users/wwwwolf/blog/2012

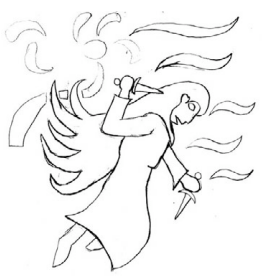

(a) sketch

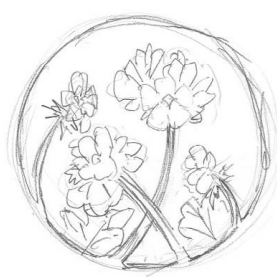

(c) sketch

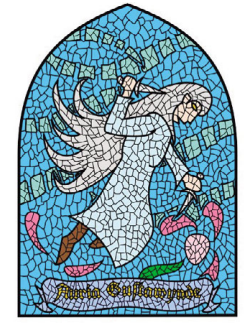

(b) stained glass

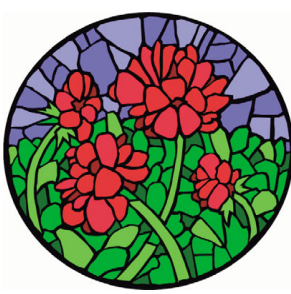

(d) stained glass
図 1 ラフスケッチ線画からのステンドグラス生成例 Examples of stained glass produced from rough sketch line drawings.

2012 年 5 月 22 日受付, 2012 年 8 月 6 日再受付, 2012 年 8 月 10 日採録 †九州大学 大学院芸術工学研究院 視覚情報部門

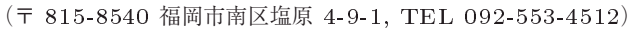

$\dagger$ Faculty of Design, Kyushu University

(4-9-1, Shiobaru, Minami-ku, Fukuoka-shi, 815-8540 Japan) /03/stained-glass-in-gimp-and-inkscape.html に示され ている生成例 (この例では背景に手が加えられている) で あり, (c),(d) は http://www.saltmanz.com/pictures/ Artwork/Chris/Digital\%20Art/Stained-Glass+Flowers +-+pencil+sketch.jpg.php の例である。このように手描 きの線画では線が閉じていない箇所も含まれる。これらの例 では図 1(a),(c) の線画を埋め込んだステンドグラスを手作 業で作り，それに彩色しているが，本稿では，ラフスケッチ の線を単純化した図 2 のような線画を埋め込んだステンド グラス風画像を自動的に生成するノンフォトリアリスティッ クレンダリング (NPR) 法を提案する. 埋め达む線画は, 図 2 のように線の途切れも含むとする。本提案法では, この ような線画をボロノイ分割に埋め达む。

最も単純な埋め込み法としては, 図 3 に示す Di Blasi ら 1) のモザイクタイル分割のように，線画に関係なく生成 したボロノイ図に線画を直接重ね描きする方法が考えられ るが，線画の線とボロノイ境界とが無関係なので，不自然 なステンドグラス画像となる。

他の方法として，王らの非等方ボロノイ分割 ${ }^{23)}$ を応用

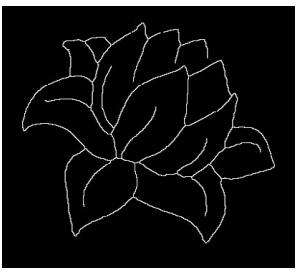

(a) lotus

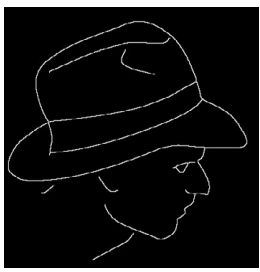

(b) hat
図 2 線画の例 Examples of line drawings. 


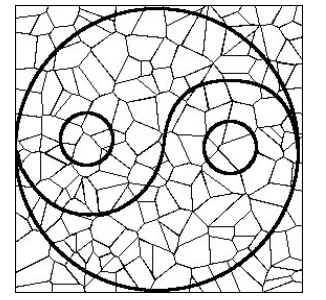

図 3 Di Blasi ら 1) のモザイクタイル分割 Mosaic tile tessellation by Di Blasi et al. ${ }^{1)}$.

することが考えられる。しかし，この非等方ボロノイ分割 は画素のカラー值に基づいており, 線画に応用するために は，線画を一旦カラー画像に変換する必要がある．線画の すべての線が閉じていれば，そのような変換が可能である が，一般には図 1 や図 2 のように線は閉じているとは限ら ないので，カラー画像には変換できず，王らの方法 ${ }^{2) 3)}$ は 本稿の目的には応用できない.

そこで本稿では, 線画の距離变換值に基づく非等方分割 ボロノイ法を用い, ボロノイセルの境界ができるだけ線画 の線に一致するようにボロノイ分割に重みを付ける。また 背景領域での無駄なセルを省くために, セルサイズを距離 值に応じて適応的に変える。

ボロノイ図に線画を埋め込む類似手法として Mould の 手法 ${ }^{4)}$ が提案されているが, 後で示すように本稿の提案法 は Mould の手法よりも入力線画の保存性が高い.

\section{2. ボロノイ分割によるステンドグラス画像}

本稿で提案するステンドグラス画像の生成手順は

1) ポアソンディスクサンプリング (PDS) によって点を配 置する.

2) その点を母点として画像をボロノイ分割する.

の 2 段階からなる.このとき, 入力線画の線がボロノイ領 域の境界線にできるだけ一致する必要がある.PDSにおい て点が入力線からある程度離れるように, 入力線画の距離 変換を利用する. 図 4(a) の線画の距離変換を図 4(b) に示 す. 距離変換は線からの最短距離を画素值とする濃淡画像 である.PDS の手順は以下である.

1) ディスクの半径 $r$ と距離の閾值 $d_{m}$ を設定する.

2) すべての画素にランダムに番号 $k$ を付ける.

3) $k=1$ とし, step 4 .

4) 画素 $k$ の距離変換值が $d_{m}$ 以上なら $\operatorname{step} 5$ ○. $d_{m}$ より 小さければstep6へ.

5) 画素 $k$ から半径 $r$ 以内に既に点が打たれていれば step6

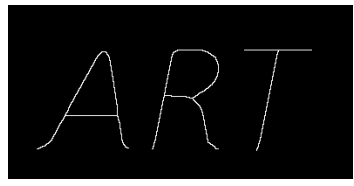

(a) input line image

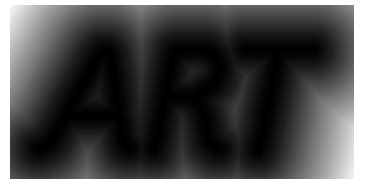

(b) distance transform
図 4 入力線画の距離変換

Distance transform of input line drawing.
へ. 打たれてなければ画素 $k$ に点を打って step6へ. 6) $k$ を 1 増やして step4へ.

図 4(a)の線画について，このPDS で打った点を母点と するボロノイ分割を図 $5(\mathrm{a})$ に示す. $r=17, d_{m}=15$ とし た。このままでは図 4(a)の線がわかり難いので, Mould ${ }^{4)}$ と同様に, 入力線画の線から距離 $\gamma$ 以内の最近傍の七ル境 界線を太くしたのが図 $5(\mathrm{~b})$ である. $\gamma=5$ とした．図 3 の Di Blasi ら ${ }^{1)}$ と違い, 図 5(b) では太い線もボロノイセ ルの境界線であり, 線画の埋め込みとしては自然であるが, 入力線画の線が途切れたり折れ曲がっており, 文字が乱れ ている.

そこで，セル境界が入力の線にできるだけ一致するため の改善として，ボロノイ分割を非等方にし，重みを付ける.

\section{1 非等方ボロノイ分割}

セルの形状を入力線に沿って歪ませると, セル境 界も入力線に沿うと期待される。そこで，上記のボ ロノイ分割での画素 $i$ と母点 $k$ の距離 $D_{i k}=$ $\sqrt{\left(x_{i}-x_{k}\right)^{2}+\left(y_{i}-y_{k}\right)^{2}}$ をバイラテラル距離 $D_{b i k}=$ $\sqrt{\left(x_{i}-x_{k}\right)^{2}+\left(y_{i}-y_{k}\right)^{2}+\alpha\left(d_{i}-d_{k}\right)^{2}}$ に拡張する。こ こで $\left(x_{i}, y_{i}\right)$ と $d_{i}$ は画素 $i$ の座標と距離変換值, $\left(x_{k}, y_{k}\right)$ と $d_{k}$ は母点 $k$ の座標と距離変換值である. 距離をこのよ うに拡張するとボロノイ分割が非等方になる。王ら 2)3)の 方法では $d_{i}$ や $d_{k}$ はカラー值であるが, ここでは距離值で ある。

上記の PDS も非等方 PDS に変える.すなわち, PDS で の画素と点間もバイラテラル距離で測る。この非等方 PDS による非等方ボロノイ分割を図 $6(\mathrm{a})$ に示す. $\alpha=0.4$ とし た. 図 6(b) は入力線近傍のセル境界を太くしたものであ る。 セル形状が入力線に沿うように歪み, 線の折れ曲がり も少し改善されているが, 図 5(b) との差は僅かである.

\section{2 重み付き等方ボロノイ分割}

非等方化とは別の改善法は母点の重み付け5)である. 図 5 のボロノイ分割ではすべての母点の重みは同じなので, 隣 接する母点の 2 等分線が境界になる。したがって，母点が入 力線から等距離にないとセル境界が入力線からずれる. 上

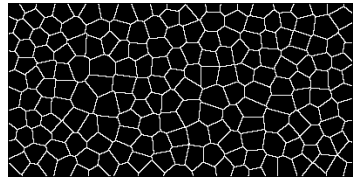

(a) isotropic VT

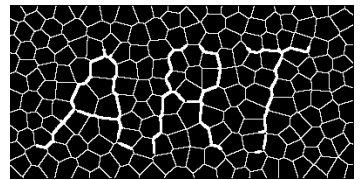

(b) thickened lines
図 5 等方ボロノイ分割 Isotropic Voronoi tessellation.

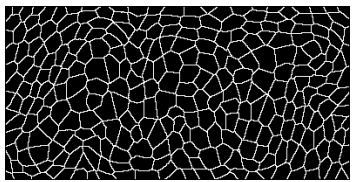

(a) anisotropic VT

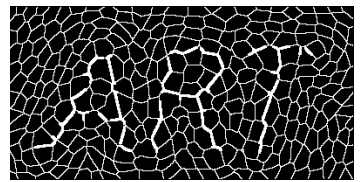

(b) thickened lines
図 6 非等方ボロノイ分割 Anisotropic Voronoi tessellation. 
記の PDS では，点は入力線から距離 $d_{m}$ 以内には打たれ ないが，正確に $d_{m}$ だけ離れるわけではない，そこで，母 点が等距離でなくてもセル境界が入力線に一致するように, 重みなし距離 $D_{i k}$ を重み付き距離 $D_{w i k}=D_{i k} / d_{k}$ に変え る.こうすると母点からセル境界までの距離の比が母点の 距離変換值の比になるので, 入力線に一致すると期待され る.この重み付き等方ボロノイ分割を図 7 に示す. 図 5 よ りも乱れが減少しているが，まだ所々で乱れが残っている。

\section{3 重み付き非等方ボロノイ分割}

以上のように，非等方化も重み付けも，それぞれ効果は 認められるが不充分である。そこで，これらの非等方化と 重み付けの両方を組合せて, 重み付きバイラテラル距離 $D_{w b i k}=D_{b i k} / d_{k}$ を用いる。この重み付き非等方ボロノイ 分割を図 8 に示す. 乱れが減って入力線が比較的良好に保 たれている。

\section{4 適応的セルサイズ重み付き非等方ボロノイ分割}

この重み付き非等方ボロノイ分割では, セルのサイズは 画像全体で均一なので, 入力線の遠方でもサイズが細かく, セルの数が不必要に多い。 そこで, 入力線から離れるにつ れてセルサイズが大きくなるように, PDS でのディスク半 径 $r$ を $r=r_{m}+p d_{k}$ に変える。この適応的セルサイズ重み 付き非等方ボロノイ分割を図 9 に示す. $r_{m}=15, p=0.1$ とした. 入力線の乱れも少なく, 七ルサイズも画像周辺で 大きくなっており，無䭾なセルが減っている.

なお, 王ら 2)3) のカラー值による非等方ボロノイ分割で は, 色が一定の背景ではセルサイズを変えるのは難しいが, 本提案法での距離変換值はすべての画素で勾配を持つので, 画像全体でセルサイズを変えることができる。これもカラー

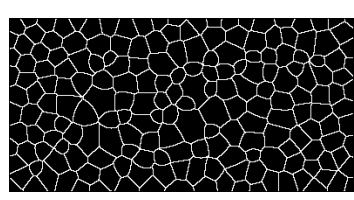

(a) weighted isotropic VT

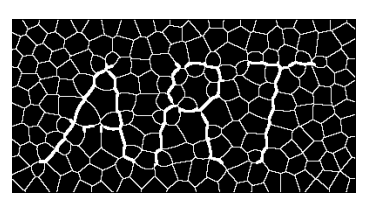

(b) thickened lines
図 7 重み付き等方ボロノイ分割

Weighted isotropic Voronoi tessellation.

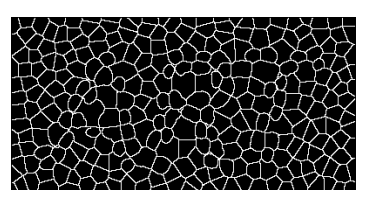

(a) weighted anisotropic VT

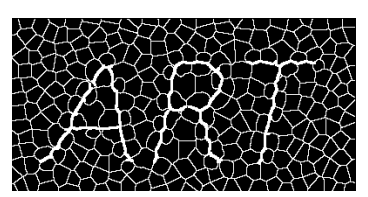

(b) thickened lines
図 8 重み付き非等方ボロノイ分割

Weighted anisotropic Voronoi tessellation.

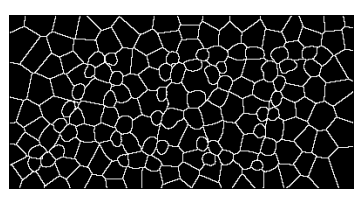

(a) adaptive cellsize WAVT

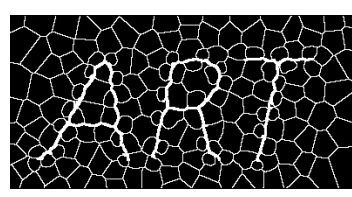

(b) thickened lines
図 9 適応的セルサイズ重み付き非等方ボロノイ分割 Adaptive cellsize weighted anisotropic Voronoi tessellation.

值でなく距離值を用いることの利点である。

図 10(b) は, 図 10(a) の入力線画での適応的セルサイズ 重み付き非等方ボロノイ分割である。図 10(c) は Mould ${ }^{4)}$ の結果画像である。困 10(b) は図 10(c) よりも入力線画の 保存性が高い.ちなみに, 入力線近傍のセル境界を太くし ないままの適応的セルサイズ重み付き非等方ボロノイ分割 をぼかしてコントラスト強調したのが図 10(d) であり，太 線化しなくても埋め込まれた線画がある程度判別できるの が分かる.

\section{3. 他の入力画像例}

図 2 の線画の適応的セルサイズ重み付き非等方ボロノイ 分割を図 11 に示す。また，他の線画の画像例での結果を 図 12 に示す. 左側が入力線画, 右側が本提案法の結果で ある。入力線画が良好にセル境界に埋め达まれている。ま た, 画像の周辺ではセルサイズが大きくなっており, 無駄 なセルが省かれている。しかし，入力の線の近くでは，ス テンドグラスとしてはセルサイズが細かくなり過ぎている. これは, 入力線画の保存性を高めるために, セルサイズの 変化を大きくしたためである。

なお，図11(a)に鉛線の凹凸と照明効果を付け加えたス

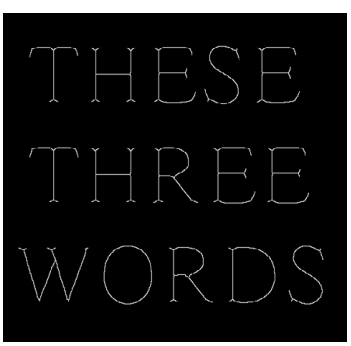

(a) input line drawings

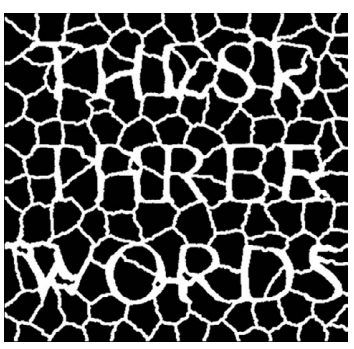

(c) Mould ${ }^{4}$

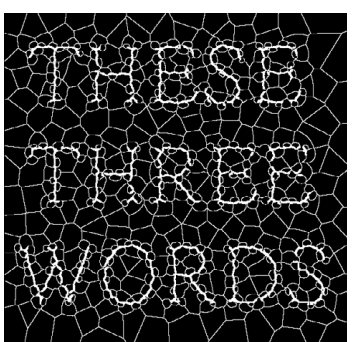

(b) WAVT with thick lines

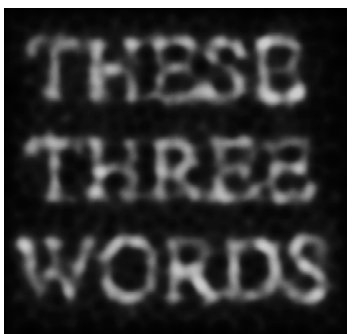

(d) blurred WAVT

図 10 Mould $^{4)}$ の結果との比較 Comparison with result by Mould ${ }^{4)}$.

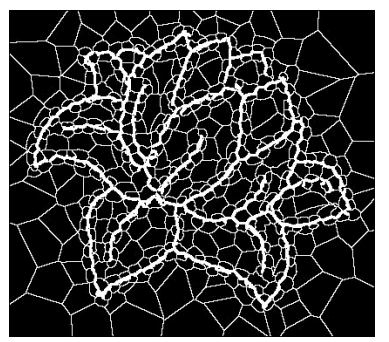

(a) WAVT of lotus

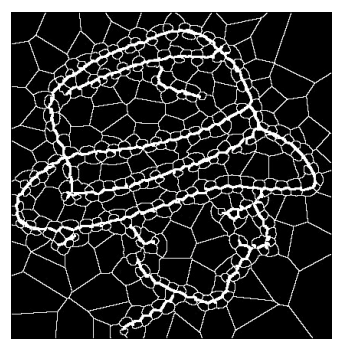

(b) WAVT of hat
図 11 図 2 の線画の結果 Results for line drawings in Fig.2. 

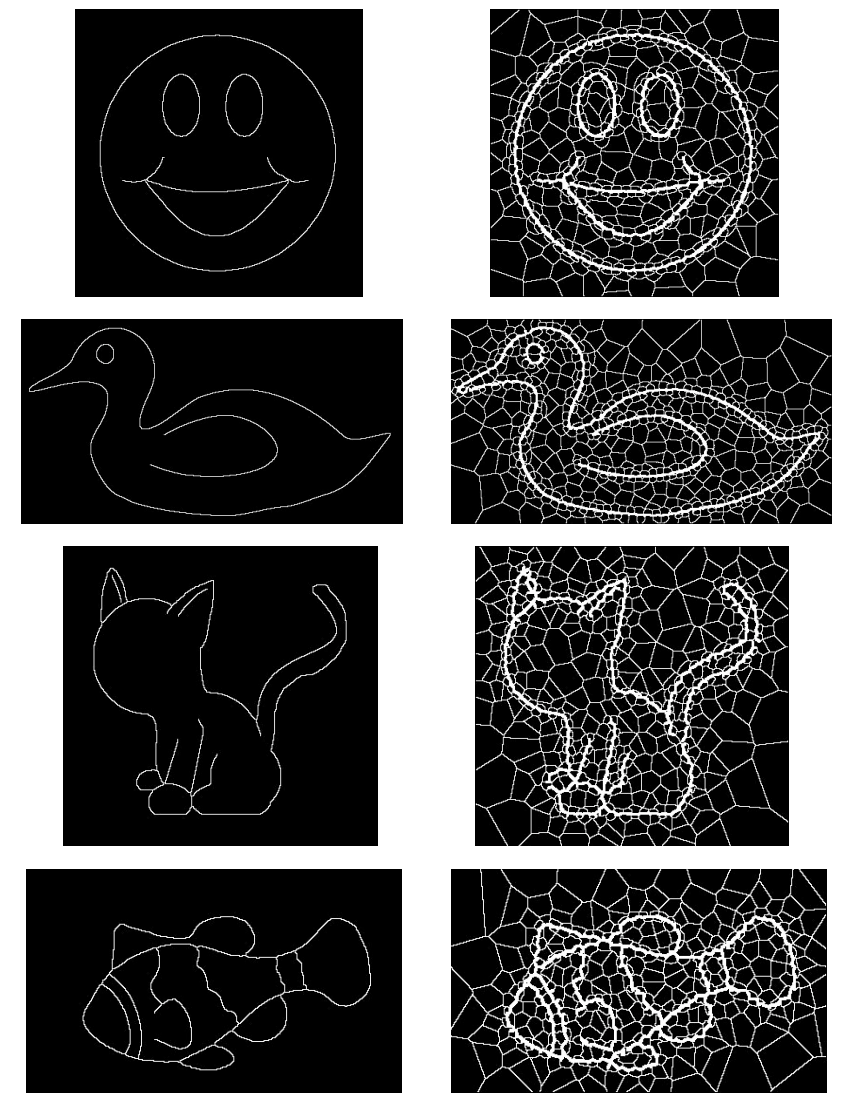

図 12 他の画像例 Other example images.

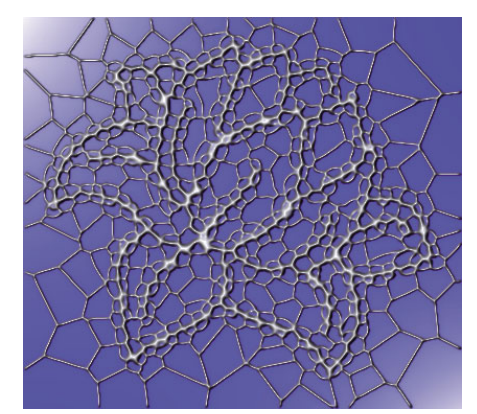

図 13 図 11(a) のステンドグラス風画像 Stained glass image of Fig.11(a).

テンドグラス風画像を図 13 に示す.

\section{4. むす び}

線からの距離変換に基づいて, 適応的セルサイズ重み付 き非等方ボロノイ分割に入力線画を埋め込んだステンドグ ラス風画像を生成するNPR 法を提案した。図 13 の結果を 見ると, 入力線画が変形しており, 判別し難い. 入力線画 がわかりやすいように, 図 $2(\mathrm{a})$ を少し太くして図 13 に重 ね描きしたのを図 14(a) に示す。また，ハスの花に色を付 けた (輪郭線を補間して途切れを埋めてから彩色した) もの を図 14(b) に示す(ただし，輪郭の途切れが大きい場合に はこのような彩色は難しいと思われる).このような後処理 を付け加えれば入力線画がわかりやすくなるが, 図 13 に 見られる線の変形の主原因は, 入力の線の近くに細かいセ

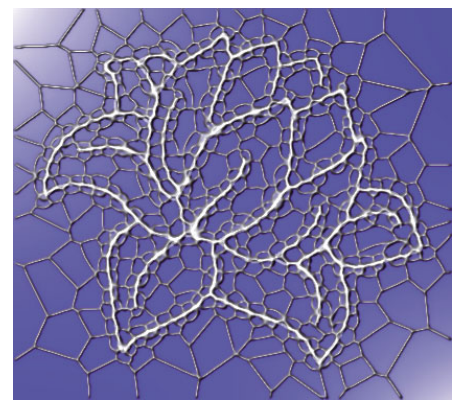

(a) Fig.13 with overlaid input lines

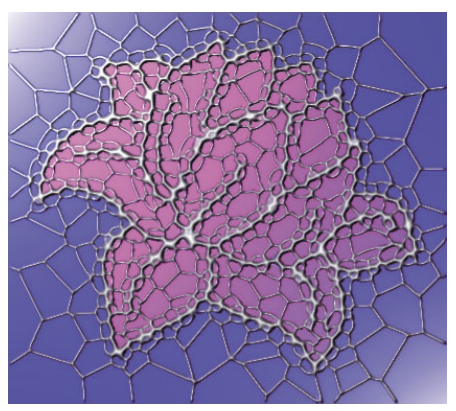

(b) Fig.13 with colored flower

図 14 図 2(a) の線を図 13 に上描きした結果と, 花に彩色し た結果

Result of overlaying lines in Fig.2(a) to Fig.13, and result of coloring flower in Fig.13.

ルが多数生成されることであり，このような細かいセルは ステンドグラスには好ましくない。それらの細かいセルを 併合すれば線の視認性が向上すると思われるので, そのよ うな併合処理を付け加えるのが今後の課題である.

最後に, 本研究は, 科研費 24500208 の助成を受けた.

\section{〔文献〕}

1) G. Di Blasi, G. Gallo and M. Petralia, "Puzzle image mosaic", Proc. IASTED/VIIP (2005)

2）王富会，浦浜喜一: “非等方ボロノイ分割によるステンドグラス画像”, 信学論, J94-A, 2, pp.149-152 (2011)

3) 王富会, 王濤, 井上光平, 浦浜喜一: “非等方重心ボロノイ分割による ステンドグラス画像”, 映情学誌, 65, 7, pp.1000-1002 (2011)

4) D. Mould: "Image-guided fracture", Proc. Graph. Interface, pp.219-226 (2005)

5) D. Ashlock, B. Karthikeyan and K. Bryden: "Non-photorealistic rendering of images as evolutionary stained glass", Proc. CEC, pp.2087-2094 (2006)

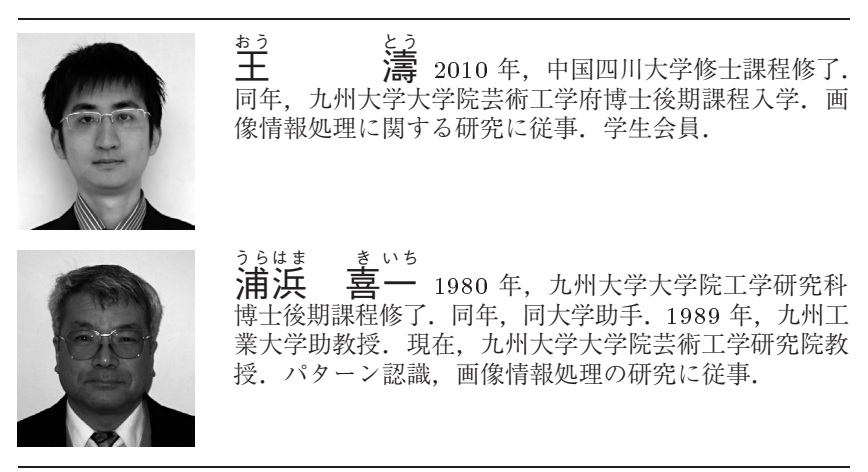

